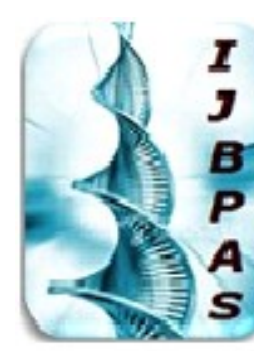

International Journal of Biology, Pharmaey and Allied Sciences (IJBPAS)

'A B Bridge Betueen Caboratory and QRendo'

Www.iibpas.com

\title{
HERBAL THERAPY FOR HYPERGLYCEMIA: A REVIEW WITH FOCUS ON TRANSDERMAL DRUG DELIVERY SYSTEM
}

\author{
MAHANT P*, SHARMA RB AND AGARWAL $S$ \\ Department of Pharmaceutics, L R Institute of Pharmacy, Solan Himachal Pradesh, India \\ *Corresponding Author: E Mail: poogrg04@gmail.com
}

Received $16^{\text {th }}$ Dec. 2019; Revised $14^{\text {th }}$ Jan. 2020; Accepted $15^{\text {th }}$ Feb. 2020; Available online $1^{\text {st }}$ Aug. 2020

https://doi.org/10.31032/IJBPAS/2020/9.8.5150

\begin{abstract}
Hyperglycemia is one of the most recognized and clinically significant disorders of the endocrine system. It is characterized by the disturbance of carbohydrate, lipid, and protein metabolism and an abnormal response to the glucose load. Different categories of anti-diabetic medicines are available in the market but due to the requirement of lifelong treatment, reductions in side effect become important. The present review is, therefore an effort to give detailed study Indian herbal drugs and plants used in the treatment of diabetes which can deliver the drug at predetermine rate for a longer duration of time in novel drug delivery system with the lesser side effect.
\end{abstract}

Keywords: Diabetes mellitus, Insulin dependent diabetes mellitus, Non insulin dependent diabetes mellitus, Word Health Organization

\section{INTRODUCTION}

In 21 centaury diabetes mellitus is one of the very common metabolic lifetime endocrine disorder [1, 2]. It occurs due to disturbance of carbohydrate, lipid and protein metabolism. Metabolic disturbance occurs if the pancreas is not able to produce enough insulin or when the body cannot properly use the produced insulin. Uncontrolled DM may

lead to severe casualty to various body systems, especially the blood vessels and nervous system [3]. The endocrine disorder has produced significant morbidity and mortality due to microvascular and macrovascular complications $[4, \mathbf{5 , 6}$. In the initial stage of type II DM some patients are symptomless while others marked with 
hyperglycemia and especially in children with insulin deficiency show polyuria, polydipsia, polyphagia, weight loss, and blurred vision. Uncontrolled DM also may lead to insensibility, coma \& prolong unconsciousness and it may cause death due to ketoacidosis [7]. It is mainly classified in various types, but the most common type is Type I \& Type II and gestational diabetes mellitus. Type I diabetes mellitus results when the pancreas fails to produce sufficient insulin due to the loss of pancreatic beta cells [8]. This form referred to as insulindependent diabetes mellitus (IDDM) or "Juvenile diabetes mellitus". The cause of this autoimmune response is nonconforming. Type II diabetes mellitus occurs when body cells resist the normal effect of insulin [9, 10]. This form assigns as NIDDM or adultonset diabetes. Gestational diabetes is the 3rd main form and occurs when women have a high blood sugar level without diabetes during pregnancy [11]. Insulin is an important anabolic hormone of the body which is responsible to regulate carbohydrate, fat \& protein metabolism. Its main function is to allow the body to use glucose (sugar) from carbohydrates present in the food for energy and to store glucose for future use. It curtails load glucose levels in the body. Insulin was the important protein discovered which contain two amino acid chains and polypeptide chain i.e. A \& B of 21 and 30 amino acid residues respectively linked with a disulfide bridge. Insulin is synthesized in beta-pancreatic cells as a preproinsulin composed of 86 amino acids. It passes through the endoplasmic reticulum and 24 amino acids are removed by enzyme action from one end of the chain, leaving another form behind. Secretions of insulin depend on the blood glucose level in the body present, pancreatic beta-cell gets activated itself if the body has a high load of glucose level and if the body has a low load of glucose in blood then beta-cell goes down [12].

\section{PLANTS WHICH HAS HYPOGLYCEMIC}

EFFECT: Over the past few years, the business of herbal medicine grew more rapidly and became prominent in developed and developing countries due to their natural origin with the lesser side effect. Many traditional medicines are in use derived from plants, minerals, and organic matter. As reported by WHO, "a medicinal plant is a plant in which one or more of its organs, contains substances that can be used for therapeutic purposes, or which are precursors for chemo-pharmaceutical semi-synthesis." Pharmaceutical companies have a great interest in such plants due to their active 
ingredients [13, 14]. Different categories of anti-diabetic medications are present in the market for the remedial action, which include insulin analogs, sulphonylureas, $\alpha$ glucosidase inhibitors, etc. this anti diabetic agent works in various ways to reduce blood glucose level [15]. However long term treatment leads to various side effects including hypoglycemia, weight gain, gastrointestinal disturbance, lactic-acidosis, etc.

There are three main groups of drugs used to control DM [16]. Sulfonylureas are $1^{\text {st }}$ group that act by increasing insulin release from the beta pancreatic cell. There are three main groups of drugs or medicines used to control DM namely Sulfonylurea's, Thiozolidinedine and alpha-glucosidase. Sulfonylurea act by increasing insulin release from pancreatic beta cells [17]. Thiozolidinediones are agonists of peroxisome proliferator activated receptor - gamma (PPAR- $\gamma)[18,19]$. The 3rd group alpha-glucosidase inhibitors reduce the digestion of polysaccharides and their bioavailability. In various countries, acarbose also used to manage type II DM and prediabetes [20]. These potent synthetic antidiabetic medicines have serious side effects and they often fail to restore glycaemic index [21-24]. Sulfonylurea derivatives some time show inhibition of hepatic regeneration, obesity, and osteoporosis. Thiazolidinedione also has serious side effects like weight gain, edema, and these side effects increase the risk of cardiovascular threats $[\mathbf{2 5}, \mathbf{2 6}]$. Due to available synthetic medicines with these side effects in the market, there is an urgent need to design an herbal novel drug delivery system to treat diabetes. Herbal drugs have the capability to guard beta cell functions and meliorate insulin resistance could be effective in preventing the progression of diabetes [27]. Some synthetic anti-diabetic drugs in the present market originated from natural sources like metformin and acarbose. Metformin is a hypoglycemic biguanide which is obtained from Galega officinalis and the precursor of acarbose is isolated from bacteria that have genus Actinoplanes. 4hydroxy isoleucine is another hypoglycemic compound extracted from Trigonella foenum-graecum [28]. Approximate out of 250000 herbal plants, only less than 25000 species have been identified which are effective against and have pharmacological efficacy against DM [29]. Therefore it is important to discover new and diabetic plant which have lesser side effect and available at low cost [30, 31].

HOW HERBS WORK AND WHY ARE THEY GOOD? 
Herbs contain a large number of naturally occurring chemicals that have a different type of biological activity. The types of environments like climate, bugs, soil quality, etc in which a plant grows also affects its quality of active pharmacological components [32]. Herbal plants are effective in many conditions like asthma, eczema, premenstrual syndrome, rheumatoid arthritis, migraine, menopausal symptoms, etc. Before using these herbal remedies one should always consult a fully trained herbalist or doctor first [33].

\section{THE LITERATURE OF ANTI-} DIABETIC MEDICINAL PLANTS: In 1998 Alarcon-Aguilara et al. theorized that more than 1200 medicinal plants are used to treat DM all over the world [34]. According to other professionals, 800 or more plants have great clinical potential to treat $\mathrm{DM}$, but only $30 \%$ of plants are used in folk remedies to treat DM. Therefore, the potential to screen new herbal anti diabetic plants is still a possibility. Various professionals focused in their recent studies on $\alpha$-glucosidase and $\alpha$-amylase inhibitors which originate from medicinal plants [35]. Surya et al. in 2014 reviewed 36 herbal remedies to treat DM, including bark of Acacia Arabica, and Acacia catechu, leaf of Aegle marmelos, root bark of Azadirachta indica, leaves of Annona squamosa, root of Andrographis paniculata, entire plant of Asparagus racemosus, bulb of Allium cepa (onion), fruit of chili Capsicum annuum, fruit of Coccinia indica, fruit of Emblica officinalis, fruit and leaves of Ficus religiosa, stem and leaves of Grewia asiatica, leaves of Mimosa pudica, and roots of Tinospora cordifolia. Neem also has the potential to reduce intestinal glucosidase activity [36, 37]. In 2013 Arumugam et al. also reviewed 33 anti diabetic plants. According to arumugam anti-diabetic plants are Axonopus compressus, Caesalpinia digyna, Catharanthus roseus, Dillenia indica, Marrubium vulgare, Semecarpus anacardium, Prosopis glandulosa, Ophiopogon japonicus, Setaria italica, Cassia auriculata, Zygophyllum album, Vitex negundo, Solanum xanthocarpum, and Alangium lamarckii [38]. According to Rahimi et.al Inula racemosa, Panax ginseng, Spergularia purpurea, and Telfairia occidentalis have the potential to reduce diabetes mellitus [39]. Sclerocarya birrea and Amaranthus spinosus were identified as a part of the repertoire of ant diabetic plants between 2005 and 2013 [40]. Many vegetables and fruits also have anti-diabetic properties with antioxidant activity. A clinical trial of Aloe Vera juice shows that it is effective to reduce blood sugar levels and 
triglyceride in diabetic patients. Extract of Curcuma longa, Panax quinquefolium, Vitis vinifera, and Stelechocarpus cauliflorus have clinical potential to protect kidney injury in diabetic patients [41, 42]. According to Giovannini et al. (2016), Psidium guajava is used to treat DM in Guatemala and South Africa. Indigenous peoples in tropical areas of South America, Central America, Mexico, Asia, India used Momordica charantia leaves and fruits as a remedy to treat DM [43]. Anacardium occidentale, the cashew tree, is widely cultivated in Africa including Zambia [44]. The stem barks and leaves of cashew are used to treat DM, kidney disease, and urinary disorders [45].

\section{MEDICINAL PLANTS FOUND IN INDIA THAT HAVE AN ANTI- DIABETIC EFFECT}

Sugar Apple: The scientific name of sugar apple is Annona squamosa. This plant has anti-diabetic activity and hypoglycemic activity. According to some professional's ethanol leaf extract of this plant, show increased level of plasma insulin $[46,47,48]$

Davana: It is an aromatic herb that has a scientific name Artemisia pallens. This herb has clinical potential to treat diabetes. The active constituent of this herb increases peripheral glucose utilization or inhibits glucose reabsorption [49].
Supari: Areca nut is another common name of supari. It is commonly used in Ayurveda and traditional Chinese medicines. Areca catechu is the scientific name of areca nut. It also has clinical potential to show hypoglycemic effect [50].

Chukkander: Chukkander is also known as beetroot. It is used as a food, food coloring and as a medicine. Beta vulgaris is its scientific name. Beet roots also show an antidiabetic effect. This herb increases glucose tolerance in OGTT [51].

Punarnava: Boerhavia diffusa is the scientific name of punarnava. According to an herbalist, this plant shows a hypoglycemic effect. It shows increase hexokinase activity, decrease glucose-6-phosphatase and fructose bis-phosphatase activity and increase plasma insulin level. It also works as an antioxidant [52, 53, 54].

Cotton Tree: Some time it is known as red silk cotton. In English, it is commonly known as kapok. Bombax ceiba is its scientific name. It shows hypoglycemic activity [55].

Palash: Butea monosperma is its scientific name. According to the herbalist, it has the potential to treat diabetes [56].

Tea: Camellia sinensis is its scientific name. It is species of evergreen shrubs. It is also known as tea shrub. It shows Anti- 
hyperglycemic activity and antioxidant activity $[57,58,59]$.

Karir: It is commonly used for the preparation of food and pickle as a spice Capparis deciduas is its scientific name. It shows Hypoglycemic, antioxidant, and hypolipidaemic activity [60].

Kankarej: In Sanskrit, it is also known as kubrakshi and in English name is fever nut. Caesalpinia bonducella is its scientific name and shows hypoglycemic activity. It helps insulin secretagogue and also shows hypolipidemic activity $[\mathbf{6 1 , 6 2}]$.

Ivy gourd: It is also known as a scarlet gourd, tindora and kowai fruit. Coccinia indica is its scientific name. It also shows hypoglycemic activity [63].

Amla: It is also known as Indian gooseberry. It is the most common constituent used in the formulation of Triphala. Emblica officinalis is its scientific name. It has capability to reduce lipid peroxidation and shows antioxidant, hypoglycemic activity [64, 65, 66].

Pitanga: Pitanga is a type of fruit it's also known as Surinam cherry. Its scientific name is Eugenia uniflora. It inhibits lipase activity and shows hypoglycemic effect [67].

Chirayata: In English, it is also called as white head. Its scientific name is Enicostema littorale. According to some professionals it increases hexokinase activity, decreases glucose 6-phosphatase and fructose 1, 6 bisphosphatase activity and shows Dosedependent hypoglycemic activity $[\mathbf{6 8 , 6 9}$.

Banyan: Its scientific name is Ficus bengalenesis. According to some researchers it shows antioxidant with hypoglycemic activity on diabetic doges [70].

Gurmar: Gurmar means "sugar destroyer". Its scientific name is Gymnema sylvestre. It shows hypolipidermic and antihyperglycemic effect [71].

China rose: Hibiscus rosa-sinesis is its scientific name. It initiates insulin release from pancreatic beta cells [72]

Sakkargand: Its scientific name is Ipomoea batatas. It has a clinical potency to reduce insulin resistance [73].

Kadavanchi: Momordica cymbalaria is its scientific name. It shows Hypoglycemic and hypolipidemic activity [74].

Curry patta: Murraya koenigii is its scientific name. It has hypoglycemic activity. It also increases glycogenesis and decreases gluconeogenesis and glycogenolysis [75].

Banana: Musa sapientum its scientific name. It has Antihyperglycemic and antioxidant activity $[\mathbf{7 6}, \mathbf{7 7}, \mathbf{7 8}]$.

Hulga: It also known as white kidney bean and its scientific name is Phaseolus vulgaris. 
It shows Hypoglycemic, hypolipidemic, inhibit alpha-amylase activity $[\mathbf{7 9}, \mathbf{8 0}, \mathbf{8 1}]$.

Anar: It is used as a medicinal purpose in the field of Ayurveda. Punica granatum is its scientific name and it acts as antioxidant and anti-hyperglycemic agent [82].

Vairi: Salacia reticulate is its scientific name. It has an inhibitory activity against sucrose and acts as an $\alpha$-glucosidase inhibitor [83].

Sweet broomweed: Scoparia dulcis its botanical name. This medicinal herb shows Insulin-secretagogue activity, antihyperlipidemic, hypoglycemic and antioxidant activity $[84,85,86]$.

Chirata: Swertia chirayita is its botanical name. It is used for a medicinal purpose in the business of Ayurveda. It stimulates insulin release from islets cells hence acts as an anti-diabetic agent [87].

Shahajire: Syzygium alternifolium its scientific name and it also shows Hypoglycemic and antihyperglycemic activity [88].

Behada: Its scientific name is Terminalia belerica. It also has the capability to act a antibacterial, hypoglycemic agent [89].

Hirda: Terminalia chebula is its scientific name and it also shows Antibacterial, hypoglycemic properties [89].
Giloya: Glioya mostly used for medicinal purpose in the field of Ayurveda. Tinospora crispa Ais its scientific name and it shows anti-hyperglycemic activity. It stimulates insulin release from pancreatic beta islets cells [90].

Sadabahar: Vinca rosea is its scientific name. According to a specialist it acts as an anti-hyperglycemic [91].

Ashvagandha: Withania somnifera is the scientific name of ashwagandha. It shows hypoglycemic, diuretic and hypocholesterolemic activities [92].

\section{FORMULATED COMMERCIALIZED HERBAL DRUGS WITH ANTI- DIABETIC PROPERTIES \\ DIABECON (Himalaya): Diabecon is a} proprietary ayurvedic medicine manufactured by Himalaya herbal healthcare. It is a phytomineral preparation used for the management of diabetes. Each tablet contains extract of Guggulu (Conniphora mukul) 30mg, Shilajitu (Asphaltum) 30mg, Mesha shringi (Gymnema sylvestre) 20mg, Pitasara (Pterocarpus marsupeum) 20mg, Yastimadhu (Glycyyhiza glabra) 20mg, Saptarangi (Casearia esculenta) 20mg, Jambu (Syzygium cumini) 20mg, Shatavri (Asparagus racemosus) 20mg, Punarnava (Boerhaavia diffusa) 20mg, Mundatika (Spheranthus indicus) 10mg, Guduchi 
(Tinospora cordifolia) 10mg, Kirata (Swertia chiraita) 10mg, Gokshura (Tribulus terrestris) 10mg, Bhumyamalaki (Phylanthus niruri) 10mg, Gambhari (Gmelina arborea)10mg, Karpasa (Gossypeum herbacium) 10mg, Daruharidra (Berberis aristata) 5mg, Kumari (Aloe barbadensis) 5mg, Triphala (Embelica officinalis, Terminalia chebula, Terminalia bellerica) 3mg. Powders of Sushavi (Momordica charantia) 20mg, Maricha (Piper nigrum) 10mg, Vishnupriya (Ocimum sanctum) 10mg, Atibala (Abutilon indica) 10mg, Haidra (Curcuma longa) 10mg, Turmeric janglipalak (Rumex maritimus) 5mg, Vidangadi lauha $27 \mathrm{mg}$.

MADHUMEHNIL (Yamuna pharmacy): Madhumehnil capsule is a ayurvedic formulation manufactured by Yamuna pharmacy. Each capsule contains Methe beej ( Trigonella foenum graecum) 100mg, Karela beej (Momordica charantia) 100mg, Haridra (Curcuma longa)100mg, Aamalki (Phyllanthes officinales) 100mg, Shilajeet $80 \mathrm{mg}$, Trivanga bhasma 20mg.

BGR-34 Tablets: blood glucose regulator 34 is an Ayurvedic derived product that is sold in India as an over-the-counter pill for the management of type 2 diabetes. It was developed in 2015 by two governmentowned laboratories (CSIR-NBRI \& CSIR-
CIMAP) and launched commercially in 2016. The raw material for BGR-34 is derived from six plants. Daruharidra (Berberis aristata), Giloy (Tinospora cordifolia), Vijaysar (Petrocarpus marsupium), Gudmar (Gymnema sylvestre), Manjeestha (Rubia cordifolia), Methi (Fenugreek).

AMREE PLUS: AMREE PLUS is a proprietary ayurvedic medicine manufactured by Aimil Pharmaceutical India Ltd, designed for the treatment of diabetes and prediabetes. It is available in the form of tablets, capsules, and granules. Each dosage form contain Gudmar (Gymnema sylvestre), Karela (Momordica charantia), Neem part (Azadirachta indica), Giloe (Trinosora cordifolia), Bilv patar (Aegle marmelos), Haridra (Curcuma longa), Karanjbeej (Pongamia pinnata), Kundru (Coccinia indica), Nishoth (Ipomoea trupethum), Jamunpatr (Eugenia jambos), Kaunch (Mucuna pruriens), Gokhru (Tribulus terrestris), Gularpatr (Ficus glomerata), Kalonji (Nigella sativa), Punernava (Boerhaavia diffusa), Bhringraj (Eclipta alba), Kalmegh (Andrographis paniculata), Bhuiamla (Phyllanthus niruri), Sitaphal beej (Cucurbita pepo), Amla (Embico officinalis), Alsi (Linum usitatissimum), Sunflower seeds (Halianthes anus), Shatavar (Asparagus 
racemosus), Bidari kand (Pueraria tuberose), Safed Musli (Asparagus adscendens), Palash pushpa (Butea monosperma), Tulsi (Ocimum sanctum), Ashwagandha (Withania somnifera), Kali jeeri (Centratherum anthelminticum), Methi beej (Trigonella foenum graecum), Kutaki (Picorrhiza kurroa), Kali Mirch (Piper nigrum)

IME-9: IME-9 tablet is a polyherbal medicine which is manufactured by Kudos Laboratories India Ltd and developed by C.C.R.A.S (Central council for research in ayurvedic sciences) Ministry of Ayush, Govt of India. Each tablet contains Amra (Mangifera indica), Karela (Momordica charantia), Gudmar (Gymnema sylvesstre), Jamun (Syzygium cumini), Shilajit (Asphaltum).

PANCREAS TONIC 180 cp: Pancreas tonic is one of the products on the market for rejuvenating the pancreas and restoring it back to normal health. Ingredients that are present in this formulation are Pterocarpus marsupium, Gymnema sylvestre, Momordica charantia, Syzygium cumini, Trigonella foenum graceum, Azadirachta indica, Ficus racemosa, Aegle marmelos, Cinnamomum tamala.

GLUCOCARE: Himalaya herbal healthcare glucocare for natural blood glucose health is a proprietary herbal formula comprised of well known and researched Ayurvedic herbs. Glucocare formula as a dietary supplement supports normal blood sugar levels. This preparation contains Indian kino tree (wood), Boerhavia (root), Casearia esculenta (stem), Gymnema (leaf), Indian sphaeranthus (flower), Jambolan (seed), Levant cotton (seed), Phyllanthus amarus (whole plant), Malay bush beech (black), Levant cotton (seed), Bitter melon (fruit), Shatavari (root), Guggul (oleo-gum-resin), Shilajeet (mineral pitch), Papper (fruit), Holy basil (leaf), Aloe Vera (leaf), Indian abutilon (root), Turmeric (rhizome), Amla (fruit), Chebulic myrobalan (fruit), Belleric myrobalan (fruit) and Ginger (rhizome).

DIA-CARE CHURNA: Dia Care Churna is an ayurvedic medicine to manage high sugar level manufactured and marketed by Isha Agro Developers Pvt. Ltd. It contains Jambu beej (Eugenia jambolona), neem bark (Aradirachta indica), Guduchi (Tinospora cordifolia), Methi seed (Trigonella foenum groecum), Karela (Mamordica charntia), Gudmar (Gymnema sylvestrej), Amla (Emblica officinalis), Mamejeva (Ericodemma littorole blume), Soptarangi (Casearia esculento), Harde (Terminalia chebula), Gokshur (Tribulus terrestris), Jethimodh (Glycyrrihra glderal), Jiroo (Cuminum cyrnium), Haldi (Curcuma longa), 
Dhania (Cariandrum sativum), Kalijiri (Vernonia anthelmintico), Black salt, Shuddha shilajit (Asphalt), Pippoli (Pipper kngrum), Mari (Piper nigrum), Sunth (Zingiber officinale), Ashwogandha (Withania somnifera).

DIABETES-DAILY CARE: This is also polyherbal formulation which contains Cinnamon 20\% extract, Alpha Lipoic Acid, Chromium Picolinate, Vanadium, Banaba Leaf $1 \%$ extract, Momordica 10\%, Fenugreek $60 \%$ extract, and Gymnema sylvestre $25 \%$.

STREAM CP-3: Stream CP-3 herbal capsules used as a unique combination of herbs which are significantly proven for herbal treatment of diabetes. This formulation is marketed by Streamline Parma private limited. These ant diabetic capsules contain Methi beej, Ghrmar, Vijyasar, Karela, Jamun, Ashwagandha, Shilajit, Shatawar, Amla, Neem patar.

GLYCODAB: Dabur India limited on Nov 14, 2017, announced the launch of a product Dabur GLYCODAB tablets in partnership with C.C.R.A.S (Ministry of Ayush, Govt of India). It is a research product of CCRS and the ministry of Ayush. A Glycodab tablet contains Karavallaka (Karela) dried fruit, Jambu seeds, Amra seeds, Meshasringi leaves. All ingredients are used in equal quantities.

DIABALIFE: This formulation manufactured by the ON\&ON company. Stabillized Allicin, Cinnamon (Cinnamomum Cassia), Karela (Momordica charantia), Elephants Scaber, Neem (Azadirachta indica), Arecanut (Areca catechu), Gudmar (Gymnema sylvestre).

DIABECURE: Diabecure herbal tablet marketed by Max Biocare. Each film-coated tablet contains Cinnamon (Cinnamomum Cassia) stem bark, Bitter melon (Momordica charantia) fruit, Fenugreek (Trigonella foenum-graecum) seed, Alpha lipoic acid, Chromic chloride hexahydrate, Chromium picolinate, Biotin, Zinc sulfate heptahydrate, Colecalciferol.

DIA-BETA PLUS: Dia-Beta Plus capsule is a proprietary ayurvedic medicine manufactured by Plant Ayurveda. This capsule is made using the herbs like Gurmaar (Gymnema sylvestrae), Karela (Momordica charantia), Saptrangi (Salacia oblonga), Vizaysaar (Pterocarpus marsupium), Ashwagandha (Withania somnifera) and Tulsi (Ocium tenuiflorum).

DIABETIC CARE: Sunova Diabetic Care is a unique synergistic combination of standardized Fenugreek (T.foenum-graceum) 
extract, Gudmar (Gymnema sylvestre) extract, Daruharidra (Berberis aristata).

\section{TRANSDERMAL DRUG DELIVERY:}

Currently, most of the medicines are available in oral dosage form and sometimes they not as beneficial as we want due to their 1 st pass metabolism. Due to this disadvantage, the transdermal drug delivery system was discovered. TDDS is a novel drug delivery system which is popular and costly due to its exclusive advantages. Transdermal patches or formulation is easy to use, and flexible to terminate drug absorption by removing the patch from the skin surface. This system improves bioavailability, controlled absorption and maintains a uniform plasma level with lesser side effect [93]. Solid dosage forms that are taken orally as a tablet, capsules, etc during metabolism face problems like enzymatic degradation, 1st pass metabolism, and this dosage form also have other disadvantages like the unpleasant taste, order color. Due to these disadvantages patients become noncompliant. Transdermal patches overcome these disadvantages and release the drug at a continuous rate for a longer duration of time and become alternative or attractive solution [94]. The drugs that achieve their systemic effect through dermal rout are known as transdermal drug delivery and it differs from topical drug delivery system [95]. These are extended-release dosage form that is capable to maintain systemic drug concentration [96, 97]. Penetration enhancer plays an important role in the formulation of transdermal patches. It helps penetrate the drug molecules through the skin as they curtail resistance of the stratum corneum without damaging viable cells. It is a painless approach to deliver the drug through the skin. The drug initially penetrates drug molecules from stratum corneum and then pass through the deeper epidermis and dermis without accumulation. A drug penetrates via dermal microcirculation and reaches to dermal layer then it becomes accessible for systemic absorption [98].

TRANSDERMAL PATCH: A transdermal patch may be defined as a medicated adhesive patch that delivers a drug at a continuous rate for a period of time at a predetermined rate through the skin membrane. Various transdermal patches are available in the market mainly based on semi-permeable membrane $[99, \mathbf{1 0 0}]$. The transdermal patch works on a principle to transport the drug across epidermis which effects systematically for a long period of time. It's controlled zero-order release, it's easy termination, its reduced side effects and the patient complaints make this type of drug 
delivery system a center of attraction for the scientists and researchers. Scopolamine transdermal patch is the 1 st patch which approved in 1979 but today various patches are available in the market, for example, scopolamine, nitroglycerin, nicotine, clonidine, fentanyl, estradiol, testosterone, lidocaine, and oxbutinin. Permeability of human skin is very limited, so the formulation of an effective transdermal patch is very challenging. To ensure transdermal patch does not irritate skin surface has become very important and it delivers drug according to desired pharmacokinetics and pharmacodynamics [101, 102].

\section{Benefits of Transdermal patch:}

1. The drug that delivers with TDDS has the capability to increase bioavailability because drug molecules avoid pre-systemic \& hepatic 1st pass metabolism.

2. Risk and inconveniences of IV therapy are avoided.

3. It requires a low dose as compared to other dosage form and it releases drugs continuously for a longer period of time.

4. It is easy terminating if any irritation or side effects occur.

5. It is easy to apply and self-application is possible.
6. This drug delivery system eliminates multiple-dose frequency hence it gives better patient compliance.

7. It is a very convenient method to deliver drug which requires only once weekly application.

8. This is a very suitable method for the patient who cannot tolerate oral dosage forms.

9. This system is suitable for nauseated and unconscious patients.

10. Drugs that degraded due to enzymatic action or due to acid present in the gastrointestinal system and require consistent plasma level are a good candidate for TDDS.

\section{Limitations of Transdermal patch}

1. It is a possibility that at the site of application it can produce local irritation.

2. Excipients and drug presence in the patch can cause erythema, itching local edema and allergic reaction.

3. It is essential the drug has a molecular weight of less than $500 \mathrm{Da}$.

4. The drug should have sufficient aqueous and lipid solubility a $\log \mathrm{P}$ (Octanol/ water) between 1 and 3 required.

5. The drugs that require high plasma level and undergo metabolism during 
passage through the skin are not a suitable candidate for TDDS.

6. The drugs that require a very high dose are not suitable for TDDS because the only low dose can be administered by this system.

\section{TYPE OF TRANSDERMAL PATCH:}

1. The single-layer drug in - adhesive: This is a single layer membrane system that contains the drug, adhesive, and other excipients. In this type, the adhesive layer not only serves to adhere to the various patch content that adheres and also responsible for the release of the drug. This adhesive layer is surrounded by a liner and backing

2. The multi-layer drug in - adhesive: This system is just like a Single layer system but it contains more than one layer usually separated by a membrane. One layer is responsible for the immediate release of drugs and another layer is responsible for the controlled release of drugs from the reservoir. This patch also has a temporary liner-layer and a permanent backing.

3. Reservoir: unlike a multi-layer drug adhesive system, the reservoir transdermal system also has a separate drug layer. In this drug layer is a liquid compartment containing a drug solution or suspension. This system is encapsulated in a shallow compartment molded from a drug-impermeable metallic plastic laminate. This patch is also backed by the backing membrane. Rate of release of drug from this system is zero order

4. Matrix: This system is also known as a monolithic device. This system has a drug layer of a semisolid matrix that contains a drug solution or suspension. The adhesive layer in this patch surrounds the drug layer, partially overlaying it.

5. Vapor Patch: In this patch adhesive layer release vapor with serving to adhere to various layers together. This type of patch mainly used for decongestion and release essential oil for up to 6 hours.

TRANSDERMAL

PATCHES

\section{COMPONENTS:}

1. Drug: This is an active component of the patch. This component is responsible for the therapeutic activity of the patch. The drug which undergoes 1st pass metabolism and which has a narrow therapeutic window are a good candidate for transdermal patch e.g. nitroglycerine and fentanyl.

2. Polymer: This is a very important component and acts as a backbone of TDDS. It should be chemically inert, non-toxic, and economic and do not decompose on storage. Examples of the polymer are cellulose derivative, HPMC, polypropylene, polyvinyl pyrrolidone, polymethylmethacrylate, etc. 
3. Permeation enhancer: This component of the patch improves the permeability of drugs through stratum corneum. There are three types of penetration enhancer which are very popular these are lipophilic system, surfactants, and two-component system. DMSO is a good example of a penetration enhancer.

4. Adhesive: It maintains intimate contact between patch and skin surface. It should have the capability to adhere with not more than applied finger pressure and exert strong holding force. Polyacrylates, polyisobutylene, and silicon-based adhesives are an example of adhesive.

5. Backing laminates: should have low modulus or high flexibility e.g. Vinyl, Polyethylene.

7. Other: expedients like plasticizers and solvent.

DRUG PERMEATION PATHWAY: Drug transport from the dosage form to the systemic circulation by various skin permeation rout including skin appendages, hair follicles and through sweat glands. The total surface area of human skin represents only 0.1 percent skin projection and this permeation route flux of drug is small. Only three main drug permeation routes identified namely appendages or shunt route, intracellular route and transcellular route. The skin absorption rate of most of the drugs from appendages route is steady-state therefore this route is not able to penetrate charged and large polar compounds $[103,104,105,106]$.

Appendages route (shunt route): In appendages route drug transport through sweat glands and their correlated sebaceous glands. This route bypass penetration via stratum corneum, therefore, it is known as the "shunt" route.

\section{Epidermal route:}

Transcellular: In transcellular route drug molecule transport across the epithelial cellular membrane. This route transports positively charged small molecules, active transport of ionic and polar compounds. This route is also responsible for endocytosis and transcytosis of macromolecules.

Paracellular: In paracellular pathway drug molecule transport through around or between the cells. There is tight junction between the cells therefore drug permeation depends on the partition coefficient (log k). Hydrophilic drugs penetrate through intracellular domains whereas lipophilic drugs penetrate through stratum corneum via intracellular route. 

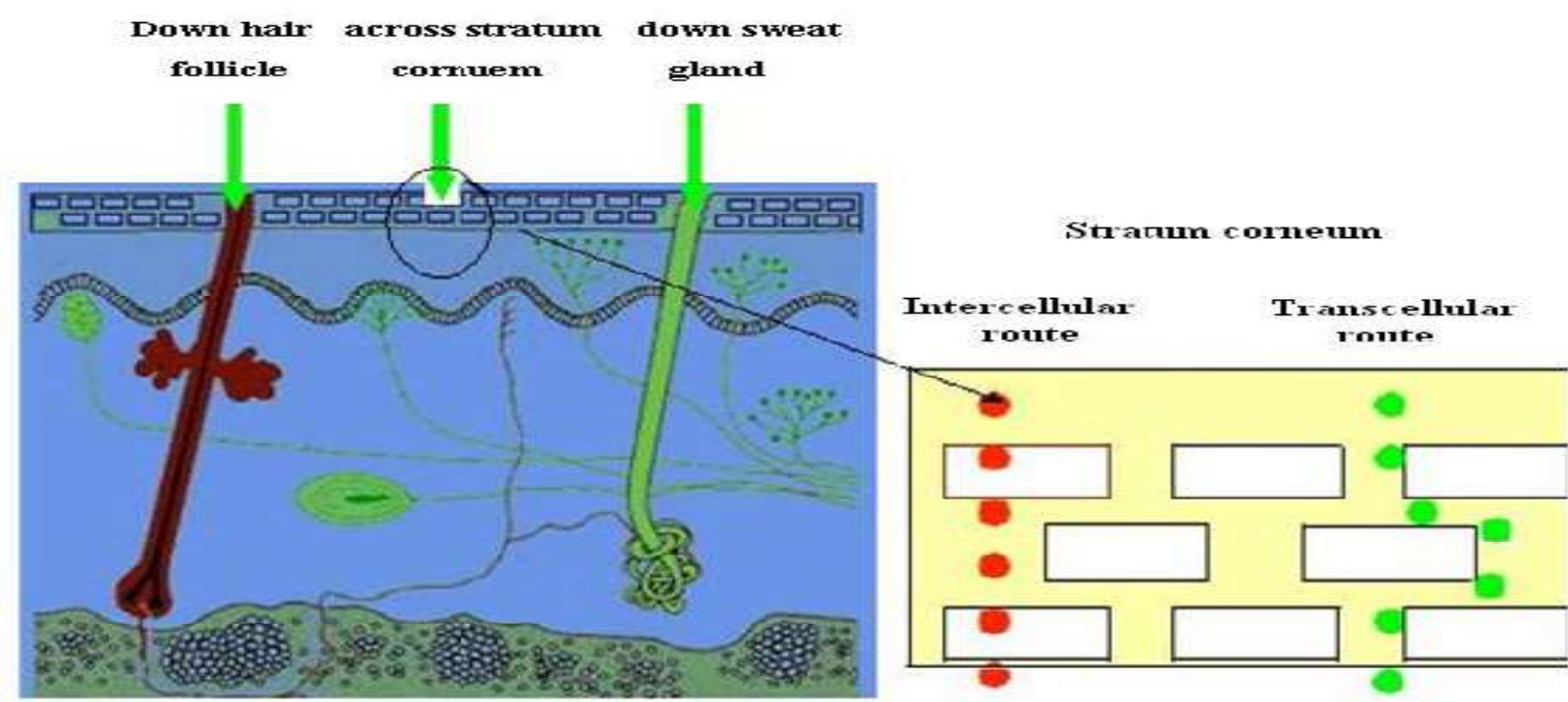

Figure 1: Drug penetration pathways across the skin

There are various steps involve in drug

ANTI-DIABETIC

HERBAL

transport through the transdermal route to

TRANSDERMAL

PATCHES

reach system circulation. These steps are: a) dissolution and release of drug from dosage form b) drug partitioning into the stratum corneum c) drug diffusion across the stratum corneum d) drug partitioning from the stratum corneum into viable epidermis layers e) diffusion across the viable epidermis layers into the dermis f) drug absorption by capillary vessels, which achieves systemic circulation [107]. The permeation of drug candidates through the skin depends on various factors. These factors are physicochemical properties, drug interactions with the membrane, and pharmacokinetic considerations. The drug which has molecular weight $<600 \mathrm{Da}$ is a good candidate for penetration through the skin [108- 111].

\section{AVAILABLE IN MARKET:}

1. Diabex natural herbal patch: It is one of the best natural solutions for diabetes \& high blood sugar level. This patch contains extract of Rehmannia, Rhizome anemarrhenae, Trichosanthin, Arrowroot, Astragalus, Scrophulariaceae, Berberin, Yam \& Borneol.

2. Dia Remedium: Dia Remedium also a herbal transdermal patch which contains Angelica sinensis, Radix pueraria, Radix rehmanniae, Radix paeoniae rubra \& Lycium barbarum.

CONCLUSION: Herbal preparation holds a huge potential for treating chronic diseases like diabetes mellitus. Herbal drugs can be formulated as synthetic ones because of their 
lower side effects, relative safety and nontoxicity and minimal development of resistance. Several drugs have been scientifically validated for the efficacy but a lot still needs to be done for their standardization and effective use.

ACKNOWLEDGMENT: Nil

CONFLICT OF INTEREST: The authors have no conflicts of interest

\section{REFERENCES}

[1] Zimmet P (2017) Diabetes and its drivers: The largest epidemic in human history? Clinical Diabetes Endocrinology 3: 1-8

[2] Awad SF, Flaherty M, Critchley J, AbuRaddad LJ (2018) Forecasting the burden of type 2 diabetes mellitus in Qatar to 2050: A novel modeling approach. Diabetes Res Clin Pract 137: 100-108.

[3] Kharroubi AT, Darwish HM (2015) Diabetes mellitus: The epidemic of the century. World J Diabetes 6: 850-867.

[4] Patel DK, Kumar R, Prasad SK, Sairam K, Hemalatha S. Antidiabetic and in vitro antioxidant potential of Hybanthus enneaspermus (Linn) F. Muell in streptozotocin-induced diabetic rats. Asian Pac J Trop Biomed. 2011; 1(4): 316-322.

[5] Ahmed AM. History of diabetes mellitus. Saudi Med J 2002. Apr; 23(4): 373-378

[6] Diabetes mellitus history- from ancient to modern times. Available at http://science.jrank.org/pages/2044/DiabetesMellitus.html (accessed on $22^{\text {nd }}$ July 2011)
[7] American Diabetes Association. Diagnosis and classification of diabetes mellitus. Diabetes Care. 2014; 37 Suppl 1:S81-S90.

[8] Atkinson M.A., Maclaren N.K., "The pathogenesis of insulin-dependent diabetes mellitus", N Engl J Med, vol. 331, pp. 14281436, 1994.

[9] Galtier F. Definition, epidemiology, risk factors. Diabetes Metab. 2010; 36: 628-651.

[10] RSSDI textbook of diabetes mellitus (Rev. 2nd edition.). Jaypee Brothers Medical Publishers. 2012. p. 235. ISBN 978-935025-489-9. Archived from the original on 14 October 2015.

[11] "Diabetes Fact sheet $\mathrm{N}^{\circ} 312 "$. WHO. October 2013. Archived from the original on 26 August 2013. Retrieved 25 March 2014.

[12] M.A. Atkinson, N.K. Maclaren, "The pathogenesis of insulin-dependent diabetes mellitus", N Engl J Med, vol. 331, pp. 1428-1436, 1994.

[13] Huai H. Ethnomedicinal analysis of toxic plants from five ethnic groups in China. Ethnobot Res Appl. 2010; 8: 169-79.

[14] Husain SZ, Malik RN, Javaid M, Bibi S. Ethonobotanical properties and uses of Medicinal plants of Morgah Biodiversity Park, Rawalpindi. Pak J Bot. 2008; 40: 1897-911.

[15] Sarah Wild, Gojka Roglic, Anders Green, Richard Sicree, Hilary K. Global prevalence of diabetes: estimates for the year 2000 and projection for 2030. 
Diabetes Care 2004; 27(5): 1047, 1053. http://doi.org/10.2337/diacare.27.5.1047

[16] Ezuruike, U.F., Prieto, J.M., 2014. The use of plants in the traditional management of diabetes in Nigeria: pharmacological and toxicological considerations. J. Ethnopharmacol. 155 (2), 857-924.

[17] Eriksson, J.W., Bodegard, J., Nathanson, D., Thuresson, M., Nystrom, T., Norhammar, A., 2016. Sulphonylurea compared to DPP-4 inhibitors in combination with metformin carries an increased risk of severe hypoglycemia, cardiovascular events, and all-cause mortality. Diabetes Res. Clin. Pract. 117, 39-47.

[18] Dawed, A.Y., Donnelly, L., Tavendale, R., Carr, F., Leese, G., Palmer, C.N., Zhou, K., 2016. CYP2C8 and SLCO1B1 variants and therapeutic response to thiazolidinediones in patients with type 2 diabetes. Diabetes Care 39 (11), 19021908.

[19] Mardinoglu, A., Boren, J., Smith, U., 2016. Confounding effects of metformin on the human gut microbiome in type 2 diabetes. Cell Metab. 23 (1), 10-12.

[20] Sun, W., Zeng, C., Liao, L., Chen, J., Wang, Y., 2016. Comparison of acarbose and metformin therapy in newly diagnosed type 2 diabetic patients with overweight and/or obesity. Curr. Med. Res. Opin. 32 (8), 1389-1396.
[21] Iwaki, M., Matsuda, M., Maeda, N., Funahashi, T., Matsuzawa, Y., Makishima, M., Shimomura, I., 2003. Induction of adiponectin, a fat-derived antidiabetic and antiatherogenic factor, by nuclear receptors. Diabetes 52 (7), 1655-1663.

[22] de Souza, C.J., Eckhardt, M., Gagen, K., Dong, M., Chen, W., Laurent, D., Burkey, B.F., 2001. Effects of pioglitazone on adipose tissue remodeling within the setting of obesity and insulin resistance. Diabetes 50 (8), 1863-1871.

[23] Meier, C., Schwartz, A.V., Egger, A., Lecka-Czernik, B., 2016. Effects of diabetes drugs on the skeleton. Bone 82 , 93-100.

[24] Rzonca, S.O., Suva, L.J., Gaddy, D., Montague, D.C., Lecka-Czernik, B., 2004. Bone is a target for the antidiabetic compound rosiglitazone. Endocrinology 145 (1), 401-406.

[25] Kole, L., Sarkar, M., Deb, A., Giri, B., 2016. Pioglitazone, an anti-diabetic drug requires sustained MAPK activation for its anti-tumor activity in MCF7 breast cancer cells, independent of the PPAR- $\gamma$ pathway. Pharmacol. Rep. 68 (1), 144-154.

[26] Tripathy, D., Schwenke, D.C., Banerji, M., Bray, G.A., Buchanan, T.A., Clement, S.C., Stentz, F.B., 2016. Diabetes incidence and glucose tolerance after the termination of pioglitazone therapy: results from ACT NOW. J. Clin. Endocrinol. Metab. 101 (5), 2056-2062. 
[27] Awasthi, A., Parween, N., Singh, V.K., Anwar, A., Prasad, B., Kumar, J., 2016. Diabetes: symptoms, cause and potential natural therapeutic methods. Adv. Diabetes Metab. 4(1), 10-23.

[28] Yin, Z., Zhang, W., Feng, F., Zhang, Y., Kang, W., 2014. $\alpha$-Glucosidase inhibitors isolated from medicinal plants. Food Sci. Hum. Wellness 3 (3), 136-174.

[29] Arumugam, G., Manjula, P., Paari, N., 2013. A review: antidiabetic medicinal plants used for diabetes mellitus. J. Acute Dis. 2 (3), 196-200.

[30] Meier, C., Schwartz, A.V., Egger, A., Lecka-Czernik, B., 2016. Effects of diabetes drugs on the skeleton. Bone 82 , 93-100.

[31] Turner, N., Zeng, X.Y., Osborne, B., Rogers, S., Ye, J.M., 2016. Repurposing drugs to target the diabetes epidemic. Trends Pharmacol. Sci. 37 (5), 379-389.)

[32] Pritesh Patel, Pinal Harde, Jagath Pillai, Nilesh Darji And Bhagirath Patel Sat Kaival College Of Pharmacy Pharmacophore (An International Research Journal Antidiabetic Herbal Drugs A Review Available Online At Review Article Pharmacophore, 2012; Vol. 3, 1829.

[33] Pritesh Patel, Pinal Harde, Jagath Pillai, Nilesh Darji And Bhagirath Patel Sat Kaival College Of Pharmacy Pharmacophore (An International Research Journal Anti diabetic Herbal Drugs A
Review Available Online At Review Article Pharmacophore, 2012; Vol. 3, 1829.

[34] Alarcon-Aguilara, F.J., Roman-Ramos, R., Perez-Gutierrez, S., Aguilar-Contreras, A., Contreras-Weber, C.C., Flores-Saenz, J.L., 1998. Study of the anti hyperglycemic effect of plants used as antidiabetics. J. Ethnopharmacol. 61 (2), 101-110.

[35] Trinh, B.T., Stark, D., Jager, A.K., 2016. Screening for potential $\alpha$-glucosidase and $\alpha$-amylase inhibitory constituents from selected Vietnamese plants used to treat type 2diabetes. J. Ethnopharmacol. 186, 189-195. (Trinh et al., 2016).

[36] Surya, S., Salam, A.D., Tomy, D.V., Carla, B., Kumar, R.A., Sunil, C., 2014. Diabetes mellitus and medicinal plants-a review. Asian Pac. J. Trop. Dis. 4 (5), 337-347.

[37] Alzohairy, M.A., 2016. Therapeutics role of Azadirachta indica (Neem) and their active constituents in disease prevention and treatment. Evid. Based Complement. Altern.Med.

2016https://doi.org/10.1155/2016/7382506 . Article ID 7382506, 11 pages

[38] Arumugam, G., Manjula, P., Paari, N., 2013. A review: antidiabetic medicinal plants used for diabetes mellitus. J. Acute Dis. 2 (3), 196-200.

[39] Rahimi, M., 2015. A review: antidiabetic medicinal plants used for diabetes mellitus. Bull. Environ. Pharmacol. Life Sci. 4 (2), 163-180. 
[40] Nasri, H., Rafieian-Kopaei, M., 2014. Protective effects of herbal antioxidants on diabetic kidney disease. J. Res. Med. Sci. 19 (1), 82-83.

[41] Giovannini, P., Howes, M.J.R., Edwards, S.E., 2016. Medicinal plants used in the traditional management of diabetes and its sequelae in Central America: a review. J. Ethnopharmacol. 184, 58-71.

[42] Nasri, H., Shirzad, H., Baradaran, A., Rafieian-kopaei, M., 2015. Antioxidant plants and diabetes mellitus. J. Res. Med. Sci. 20 (5), 491-502.

[43] Giovannini, P., Howes, M.J.R., Edwards, S.E., 2016. Medicinal plants used in the traditional management of diabetes and its sequelae in Central America: a review. J. Ethnopharmacol. 184, 58-71.

[44] Later, T., 1990. A note on the carpenter moth Salagena sp., a new pest of cashew in Zambia. Int. J. Pest Manag. 36 (3), 276278.

[45] Egwim, E., 2005. Hypoglycemic potencies of crude ethanolic extracts of cashew roots and unripe pawpaw fruits in guinea pigs and rats. J. Herb. Pharmacother. 5 (1), 27 34.

[46] Kaleem M., Asif M., Ahmed Q.U., Bano B. Antidiabetic and antioxidant activity of Annona squamosa extract in streptozotocin-induced diabetic rats. Singapore Med. J. 2006; 47: 670-675.

[47] Gupta R.K., Kesari A.N., Murthy P.S., Chandra R., Tandon V., Watal G.
Hypoglycemic and antidiabetic effect of ethanolic extract of leaves of Annona squamosa L. in experimental animals. J. Ethnopharmacol. 2005; 99: 75-81.

[48] Gupta R.K., Kesari A.N., Watal G., Murthy P.S., Chandra R., Tandon V. Nutritional and hypoglycemic effect of fruit pulp of Annona squamosa in normal healthy and alloxan-induced diabetic rabbits. Ann. Nutr. Metab. 2005; 49: 407413.

[49] Subramonium A., Pushpangadan P., Rajasekharan A., Evans D.A., Latha P.G., Valsaraj R. Effects of Artemisia pallens Wall. On blood glucose levels in normal and alloxan-induced diabetic rats. J. E thnopharmacol. 1996; 50: 13-17.

[50] Chempakam B. Hypoglycemic activity of arecoline in betel nut Areca catechu L. Ind. J. Exp. Biol. 1993; 31:474-475.

[51] Yoshikawa M., Murakami T., Kadoya M., Matsuda H., Muraoka O., Yamahara J., Murakami N. Medicinal foodstuff. III. Sugar beet. Hypoglycemic oleanolic acid oligoglycosides, betavulgarosides I, II, III and IV, from the root of Beta vulgaris L. Chemical and Pharmaceutical Bulletin. 1996; 44: 1212-1217.

[52] Pari L., Amarnath Satheesh M. Antidiabetic activity of Boerhavia diffusa $L$. effect on hepatic key enzymes in experimental diabetes. J. Ethnopharmacol. 2004; 91: 109-113. 
[53] Satheesh M.A., Pari L. Antioxidant effect of Boerhavia diffusa $L$. in tissues of alloxan-induced diabetic rats. Indian $\mathrm{J}$. Exp. Biol. 2004; 42: 989-992.

[54] Pari L., Amarnath Satheesh M. Antidiabetic effect of Boerhavia diffusa: effect on serum and tissue lipids in experimental diabetes. J. Med. Food. 2004; 7: 472-476.

[55] Saleem R., Ahmad M., Hussain S.A., Qazi A.M., Ahmad S.I., Qazi H.M., Ali M., Faizi S., Akhtar S., Hussain S.N. Hypotensive, hypoglycemic and toxicological studies on the flavonol Cglycoside shamimin from Bombax ceiba. Planta Medica. 1999; 5: 331-334.

[56] Somani R., Kasture S., Singhai A.K. Antidiabetic potential of Butea monosperma in rats. Fitoterapia. 2006; 77: 86-90.

[57] Gomes A., Vedasiromoni J.R., Das M., Sharma R.M., Ganguly D.K. Antihyperglycemic effect of black tea (Camellia sinensis) in rats. J. Ethnopharmacol. 1995; 45: 223-226.

[58] Devasagayam T.P.A., Kamat J.P., Mohan H., Kesavan P.C. Caffeine as an antioxidant: Inhibition of lipid peroxidation induced by reactive oxygen species in rat liver microsomes. Biochim. Biophys. Acta. 1996; 1282: 63-70.

[59] Agarwal V., Chauhan B.M. A study on composition and hypolipidemic effect of dietary fiber from some plant foods. Plant Foods Human Nutr. 1988; 38: 189-197.

[60] Chakrabarti S., Biswas T.K., Seal T., Rokeya B., Ali L., Azad Khan A.K., Nahar N., Mosihuzzaman M., Mukherjee B. Antidiabetic activity of Caesalpinia bonducella $\mathrm{F}$. in chronic type 2 diabetic model in Long-Evans rats and evaluation of insulin secretagogue property of its fractions on isolated islets. J. Ethnopharmacol. 2005; 97: 117-122.

[61] Chakrabarti S., Biswas T.K., Rokeya B., Ali L., Mosihuzzaman M., Nahar N., Khan A.K., Mukherjee B. Advanced studies on the hypoglycemic effect of Caesalpinia bonducella $\mathrm{F}$. in type 1 and 2 diabetes in Long Evans rats. J. Ethnopharmacol. 2003; 84: 41-46.

[62] Sharma S.R., Dwivedi S.K., Swarup D. Hypoglycemic, antihyperglycemic and hypolipidemic activities of Caesalpinia bonducella seeds in rats. J. Ethnopharmacol. 1997; 58: 39-44.

[63] Kamble S.M., Kamlakar P.L., Vaidya S., Bambole V.D. Influence of Coccinia indica on certain enzymes in the glycolytic and lipolytic pathway in human diabetes. Indian J. Med. Sci. 1998; 52: 143-146.

[64] Bhattacharya A., Chatterjee A., Ghosal S., Bhattacharya S.K. Antioxidant activity of active tannoid principles of Emblica officinalis (amla) Indian J. Exp. Biol. 1999; 37: 676-680. 
[65] Kumar K.C.S., Muller K. Medicinal plants from Nepal, II. Evaluation as inhibitors of lipid peroxidation in biological membranes. J. Ethnopharmacol. 1999; 64: 135-139.

[66] Devasagayam T.P.A., Subramanian M., Singh B.B., Ramanathan R., Das N.P. Protection of plasmid pBR322 DNA by flavonoids against single-strand breaks induced by singlet molecular oxygen. J. Photochem. Photobiol. 1995; 30: 97-103.

[67] Arai I., Amagaya S., Komatzu Y., Okada M., Hayashi T., Kasai M., Arisawa M., Momose Y. Improving the effects of the extracts from Eugenia uniflora on hyperglycemia and hypertriglyceridemia in mice. J. Ethnopharmacol. 1999; 68: 307314.

[68] Maroo J., Vasu V.T., Gupta S. Dosedependent hypoglycemic effect of aqueous extract of Enicostema littorale blume in alloxan-induced diabetic rats. Phytomedicine. 2003; 10: 196-199.

[69] Vijayvargia R., Kumar M., Gupta S. Hypoglycemic effect of aqueous extract of Enicostema littorale Blume (chhota chirayata) on alloxan-induced diabetes mellitus in rats. Indian J. Exp. Biol. 2000; 38: 781-784.

[70] Augusti K.T., Daniel R.S., Cherian S., Sheela C.G., Nair C.R. Effect of Leucoperalgonin derivative from Ficus bengalensis Linn. On diabetic dogs. Indian J. Med. Res. 1994; 99: 82-86.
[71] Preuss H.G., Jarrell S.T., Scheckenbach R., Lieberman S., Anderson R.A. Comparative effects of chromium, vanadium and Gymnema sylvestre on sugar-induced blood pressure elevations in SHR. J. Am. Coll. Nutr. 1998; 17: 116-123.

[72] Sachadeva A., Khemani L.D. A preliminary investigation of the possible hypoglycemic activity of Hibiscus rosasinensis. Biomed. Environ. Sci. 1999; 12: 222-226.

[73] Kusano S., Abe H. Antidiabetic activity of whites skinned potato (Ipomoea batatas) in obese Zucker fatty rats. Biolog. Pharmaceut. Bull. 2000; 23: 23-26.

[74] Rao B.K., Kessavulu M.M., Giri R., Apparao C. Antidiabetic and hypolipidemic effects of Momordica cymbalaria Hook fruit powder in alloxandiabetic rats. J. Ethnopharmacol. 1999; 67: 103-109.

[75] Khan B.A., Abraham A., Leelamma S. Hypoglycemic action of Murraya koenigii (curry leaf) and Brassica juncea (mustard) mechanism of action. Ind. J. Biochem. Biophys. 1995; 32: 106-108.

[76] Dhanabal S.P., Sureshkumar M., Ramanathan M., Suresh B. Hypoglycemic effect of ethanolic extract of Musa sapientum on alloxan-induced diabetes mellitus in rats and its relation with antioxidant potential. J. Herb. Pharmacother. 2005; 5: 7-19. 
[77] Pari L., Umamaheswari J. Antihyperglycaemic activity of Musa sapientum flowers: effect on lipid peroxidation in alloxan diabetic rats. Phytother. Res. 2000; 14: 136-138.

[78] Pari L., Maheswari J.U. Hypoglycemic effect of Musa sapientum L. in alloxaninduced diabetic rats. J. Ethnopharmacol. 1999; 68: 321-325.

[79] Tormo M.A., Gil-Exojo I., Romero de Tejada A., Campillo J.E. Hypoglycemic and anorexigenic activities of an alphaamylase inhibitor from white kidney beans (Phaseolus vulgaris) in Wistar rats. Br. J. Nutr. 2004; 92: 785-790.

[80] 94. Pari L., Venkateswaran S. Protective role of Phaseolus vulgaris on changes in the fatty acid composition in experimental diabetes. J. Med. Food. 2004; 7: 204-209.

[81] Knott R.M., Grant G., Bardocz S., Pusztai A., de Carvalho., Hesketh J.E. Alterations in the level of insulin receptor and GLUT4 mRNA in skeletal muscle from rats fed a kidney bean (Phaseolus vulgaris) diet. Int. J. Biochem. 1992; 24: 897-902.

[82] Jafri M.A., Aslam M., Javed K., Singh S. Effect of Punica granatum Linn. (flowers) on blood glucose level in normal and alloxan-induced diabetic rats. J. Ethnopharmacol. 2000; 70: 309-314.

[83] Yoshikawa M., Murakami T., Yashiro K., Matsuda H. Kotalanol, a potent $\alpha$ glucosidase inhibitor with the sugar sulfonium sulfate structure, from antidiabetic Ayurvedic medicine Salacia reticulata. Chem Pharma. Bulletin. 1998; 46: 1339-1340.

[84] Pari L., Latha M. Antidiabetic effect of Scoparia dulcis: effect on lipid peroxidation in streptozotocin diabetes. Gen. Physiol. Biophys. 2005; 24: 13-26.

[85] Pari L., Latha M. Antihyperlipidemic effect of Scoparia dulcis (sweet broomweed) in streptozotocin diabetic rats. J. Med. Food. 2006; 9: 102-107.

[86] Latha M., Pari L., Sitasawad S., Bhonde R. Insulin-secretagogue activity and cytoprotective role of the traditional antidiabetic plant Scoparia dulcis (Sweet Broomweed) Life Sci. 2004; 75: 20032014.

[87] Saxena A.M., Bajpai M.B., Murthy P.S., Mukherjee S.K. Mechanism of blood sugar lowering by a Swerchirin-containing hexane fraction (SWI) of Swertia chirayita. Ind. J. Exp. Biol. 1993; 31: 178181.

[88] Rao B.K., Rao C.H. Hypoglycemic and antihyperglycemic activity of Syzygium alternifolium (Wt.) Walp. seed extracts in normal and diabetic rats. Phytomedicine. 2001; 8: 88-93.

[89] Sabu M.C., Kuttan R. Anti-diabetic activity of medicinal plants and their relationship with their antioxidant property. J. Ethnopharmacol. 2002; 81: 155-160. 
[90] Noor H., Ashcroft S.J. Pharmacological characterization of the anti-hyperglycemic properties of Tinospora crispa extract. J. Ethnopharmacol. 1998; 62: 7-13.

[91] Chattopadhyay S.R., Sarkar S.K., Ganguly S., Banerjee R.N., Basu T.K. Hypoglycemic and anti-hyperglycemic effect of Vinca rosea Linn. Ind. J. Physiol. Pharmacol. 1991; 35: 145-151.

[92] Adallu B., Radhika B. Hypoglycemic, diuretic and hypocholesterolemic effect of winter cherry (Withania somnifera, Dunal) root. Indian J. Exp. Biol. 2000; 38: 607 609.

[93] Ahmed A, Karki N, Charde R, Charde M, Ganghare B. Transdermal Drug Delivery System an Overview. Int $\mathrm{J}$ Biomed Adv Res. 2011; 2: 38-56.

[94] Patel A, Visht S, Sharma PK. Transdermal Drug Delivery System: Next Generation Patches. J Drug Discov Dev. 1: 43-65.

[95] Yadav SK, Mishra VL, Vamshi KJ. Formation and Evaluation of Trans dermal Patch for Antirheumatic Ayurvedic Medicine Using Different Polymers Compositions: In Vitro. J Global Trends Pharma Sci. 2013; 4: 999-1006.

[96] Balaji P, Thirumal M, Gowri R, Divya V, Ramaswamy V. Design and evaluation of matrix type of transdermal patches of methotrexate. Int J Pharm Chem Biol Sci. 2012; 2: 464-71.

[97] Funke AP, Schiller R, Motzkus HW, Günther C, Müller RH, Lipp R.
Transdermal delivery of highly lipophilic drugs: In vitro fluxes of antiestrogens, permeation enhancers, and solvents from liquid formulations. Pharm Res. 2002; 19: $661-8$

[98] Guy RH. Current status and future prospects of transdermal drug delivery. Pharm Res. 1996; 13: 1765-9.

[99] Wilson Ellen Jett,2011 Three Generations: The Past, Present, and Future of Transdermal Drug Delivery Systems.

[100] Shingade, G.M., Aamer, Q., Sabale, P.M., Grampurohit, N.D., Gadhave , M.V.,2012. Review on: recent trend on transdermal drug delivery system, Journal of Drug Delivery \& Therapeutics 2(1), 66-75.

[101] Prausnitz, M.R., Langer, R., 2008. Transdermal drug delivery, Nat Biotechnol. 26(11), 1261-1268.

[102] .Robert L. Transdermal Drug Delivery: past progress, current status, and future prospects. Adv Drug Del Rev 2004; 56: 557-558.

[103] Alexander, A.; Dwivedi, S.; Ajazuddin; Giri, T.K.; Saraf, S.; Saraf, S.; Tripathi, D.K. Approaches for breaking the barriers of drug permeation through transdermal drug delivery. J. Control. Rel., v.164, n.1, p.26-40, 2012.

[104] Desai, P.R.; Shah, P.P.; Hayden, P.; Singh, M. Investigation of follicular and nonfollicular pathways for polyarginine and oleic acid modified nanoparticles. Pharm. Res., v.30, n.4, p.1037-49, 2013. 
[105] Frasch, H.F.; Barbero, A.M. Application of numerical methods for diffusion-based modeling of skin permeation. Adv. Drug Deliv. Rev.,v. 65, n.2, p. 208-220, 2013.

[106] Notman, R.; Anwar, J. Breaching the skin barrier - Insights from the molecular simulation of model membranes. Adv. Drug Deliv. Rev., v.65, n.2, p.237-250, 2013.

[107] Kalia, Y.N.; Guy, R.H. Modeling transdermal drug release. Adv. Drug Deliv. Rev., v.48, n.2-3, p.159-172, 2001.

[108] Moser, K.; Kriwet, K.; Naik, A.; Kalia, Y.N.; Guy, R.H. Passive skin penetration enhancement and its quantification in vitro.
Eur. J. Pharm. Biopharm., v.52, n.2, p.103$112,2001$.

[109] Farahmand, S.Maibach, H.I. Transdermal drug pharmacokinetics in man: Interindividual variability and partial prediction. Int. J. Pharm., v.367, n.1-2, p.115, 2009.

[110] Williams, A.C.; Barry, B.W. Penetration enhancers. Adv. Drug Deliv. Rev., v.64, p.128-137, 2012.

[111] Delgado-Charro, M.B.; Guy, R.H. Effective use of transdermal drug delivery in children. Adv. Drug Deliv. Rev., v.73, p.63-82, 2014. 